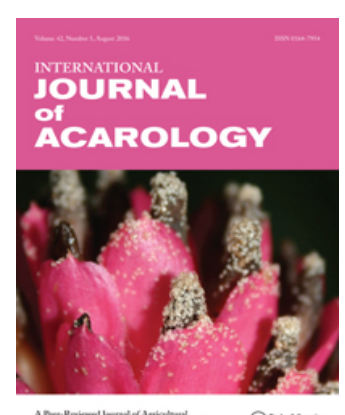

International Journal of Acarology

\title{
Syringophilid quill mites (Acari: Syringophilidae) parasitizing passerines (Aves: Passeriformes) in Brazil
}

\section{Maciej Skoracki, Sergey V. Mironov, Fabio A. Hernandes \& Michel P. Valim}

To cite this article: Maciej Skoracki, Sergey V. Mironov, Fabio A. Hernandes \& Michel P. Valim (2016) Syringophilid quill mites (Acari: Syringophilidae) parasitizing passerines (Aves: Passeriformes) in Brazil, International Journal of Acarology, 42:5, 252-257, DOI: 10.1080/01647954.2016.1179673

To link to this article: https://doi.org/10.1080/01647954.2016.1179673

\section{曲 Published online: 02 May 2016.}

\section{Submit your article to this journal ๘}

III Article views: 48

View Crossmark data 


\title{
Syringophilid quill mites (Acari: Syringophilidae) parasitizing passerines (Aves: Passeriformes) in Brazil
}

\author{
Maciej Skoracki ${ }^{a}$, Sergey V. Mironov ${ }^{b}$, Fabio A. Hernandes ${ }^{c}$ and Michel P. Valim ${ }^{d}$ \\ aDepartment of Animal Morphology, Faculty of Biology, Adam Mickiewicz University, Poznan, Poland; bZoological Institute, Russian Academy of \\ Sciences, St. Petersburg, Russia; 'Departamento de Zoologia, Universidade Estadual Paulista, Rio Claro, Brazil; dMuseu de Zoologia da Universidade \\ de São Paulo, Ipiranga, Brazil
}

\begin{abstract}
Two new quill mite species collected from passerine birds in Brazil are described: Torotrogla synallaxis sp. nov. from Synallaxis spixi Sclater (Funariidae) and Syringophilopsis bonariensis sp. nov. from Molothrus bonariensis (Gmelin) (Icteridae). Additionally, three syringophilid species were recorded from new host species captured in Minas Gerais, Brazil: Syringophilopsis tyranni Bochkov and Galloway, 2004 from Satrapa icterophrys (Vieillot) (Tyrannidae); Syringophiloidus stawarczyki Skoracki, 2004 from Dacnis cayana (Linnaeus) (Thraupidae) and Syringophiloidus parapresentalis Skoracki, 2011 from Turdus rufiventris Vieillot (Turdidae). The syringophilid fauna presently recorded from Brazil is summarized.

http://zoobank.org/urn:Isid:zoobank.org:pub:XXXX
\end{abstract}

\section{ARTICLE HISTORY}

Received 5 March 2016 Accepted 11 April 2016

Published online 2 May 2016

\section{KEYWORDS}

Birds; ectoparasites; Brazil; quill mites; Syringophilidae

\section{Introduction}

The mite family Syringophilidae (Acari: Prostigmata: Cheyletoidea) presently comprises 334 described species grouped in 60 genera. These mites have been recorded from over 480 bird species representing 95 families and 24 orders and are found in all zoogeographical regions, except Antarctica (Skoracki et al. 2012b; Glowska et al. 2015). As permanent and obligate ectoparasites, syringophilids are specialized for living inside the cavities of quills and exhibit a high level of host specificity, being mostly represented by mono- or stenoxenous parasites (Skoracki 2011; Skoracki et al. 2012b).

In Brazil, the fauna of Syringophilidae is extremely poorly known and currently is represented by only 16 species in 10 genera (including the taxa described herein) recorded from birds of the orders Charadriiformes, Columbiformes, Passeriformes, Piciformes, Psittaciformes and Tinamiformes (Table 1). It is worth noting that 21 avian species recorded as hosts of syringophilid mites constitute merely $1 \%$ of the whole avian biodiversity of Brazil (1919 bird species - Piacentini et al. 2015).

In the present paper, two new syringophilid species, belonging to the genera Torotrogla Kethley, 1970 and Syringophilopsis Kethley, 1970, are described. New host records for three quill mite species, Syringophilopsis tyranni Bochkov et Galloway, 2004, Syringophiloidus parapresentalis Skoracki, 2011 and Syringophiloidus stawarczyki Skoracki, 2004, are also reported. Additionally, all previous records of quill mites from birds in Brazil are summarized.

\section{Material and methods}

The material used in the present study was collected by S.V. Mironov, F.A. Hernandes and M.P. Valim from live birds in the course of the field expedition to Minas Gerais (Brazil) in 2010. Birds were captured by mist nets and after a manual examination of them under a dissecting microscope for the presence of ectoparasitic mites were released to the wild. Mites were stored in $96 \%$ ethanol and mounted in the Hoyer's medium according to the standard technique for these mites. Slide-mounted mites were examined under a light microscope (ZEISS Axioscope $2^{\mathrm{TM}}$ ) with differential interference contrast optics. Drawings were made with the drawing attachment. All measurements are given in micrometres. Measurements (ranges) of paratypes are given in brackets following data for a holotype. In the descriptions, the idiosomal setation follows Grandjean (1939) as adapted for Prostigmata by Kethley (1990). The nomenclature of leg chaetotaxy follows that proposed by Grandjean (1944). The morphological terminology follows Skoracki (2011). The scientific names of the birds follow Clements et al. (2014). Specimen depositories and reference numbers are displayed using the following abbreviations: AMU, Adam Mickiewicz University, Department of Animal Morphology, Poznan, Poland; MZUSP, Museu de Zoologia da Universidade de São Paulo, São Paulo, SP, Brazil; ZISP, Zoological Institute, Russian Academy of Sciences, St. Petersburg, Russia.

\section{Results}

Family Syringophilidae Lavoipierre, 1953

Subfamily Syringophilinae Lavoipierre, 1953 Torotrogla synallaxis sp. nov.

(Figures 1(a,b) and 2(a-e)).

\section{Description}

Female, holotype. Total body length 725 (725-750 in four paratypes). Gnathosoma. Hypostomal apex with pair of short, wide and blunt-ended protuberances. Each medial branch of peritremes with four chambers, each lateral branch with five chambers. Stylophore constricted posteriorly, 205 (200-205) long. Idiosoma. Propodonotal shield punctate, deeply concave on anterior and posterior margins, bearing bases of setae vi, ve, si and $c 1$. Length ratio of setae vi:ve:si 1:1.5:3.2. Setae se situated anterior to level of setae $c 1$. Pair of hysteronotal shields punctate, bearing on anterior margin bases of setae d1. Pygidial shield well sclerotized, punctate, with rounded anterior margin. All coxal fields punctate. Legs. Setae $t c^{\prime}$ and $t c^{\prime \prime}$ of legs III and IV subequal in length. Fan-like setae $p^{\prime}$ and $p^{\prime \prime}$ of legs III and IV with 10 tines. Lengths of setae: vi 
Table 1. Quill mites of the family Syringophilidae parasitizing birds in Brazil.

\begin{tabular}{|c|c|c|c|c|}
\hline Quill mite species & Host species & Host order and family & $\begin{array}{c}\text { Distribution in } \\
\text { Brazil }\end{array}$ & References \\
\hline \multicolumn{5}{|l|}{ Subfamily Syringophilinae } \\
\hline Castosyringophilus mucuya (Casto, 1980) & $\begin{array}{l}\text { Brotogeris versicolurus (St. } \\
\text { Müller) }\end{array}$ & Psittaciformes: Psittacidae & Unknown locality & Bochkov and Fain (2003) \\
\hline$"$ & $\begin{array}{l}\text { Columbina squammata } \\
\text { (Lesson) }\end{array}$ & $\begin{array}{l}\text { Columbiformes: } \\
\text { Columbidae }\end{array}$ & Unknown locality & Bochkov and Fain (2003) \\
\hline$"$ & $\begin{array}{l}\text { Columbina talpacoti } \\
\text { (Temminck) }\end{array}$ & $\begin{array}{l}\text { Columbiformes: } \\
\text { Columbidae }\end{array}$ & Bahia & $\begin{array}{l}\text { Skoracki and Glowska } \\
\text { (2008) }\end{array}$ \\
\hline $\begin{array}{l}\text { Charadriphilus vanelli Bochkov, Fain et Skoracki, } \\
2004\end{array}$ & Vanellus chilensis (Molina) & $\begin{array}{l}\text { Charadriiformes: } \\
\text { Charadriidae }\end{array}$ & Unknown locality & Bochkov et al. (2004) \\
\hline $\begin{array}{l}\text { Megasyringophilus kethleyi Fain, Bochkov et Mironov, } \\
2000\end{array}$ & Aratinga jandaya (Gmelin) & Psittaciformes: Psittacidae & Unknown locality & Fain et al. (2000) \\
\hline$"$ & Eupsittula pertinax (Linnaeus) & Psittaciformes: Psittacidae & Unknown locality & Bochkov and Fain (2003) \\
\hline 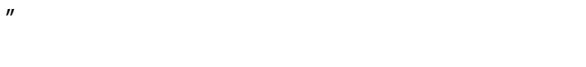 & $\begin{array}{l}\text { Brotogeris versicolurus (St. } \\
\text { Müller) }\end{array}$ & Psittaciformes: Psittacidae & Unknown locality & Bochkov and Fain (2003) \\
\hline $\begin{array}{l}\text { Neoaulobia aratingae Fain, Bochkov et Mironov, } \\
2000\end{array}$ & Aratinga jandaya (Gmelin) & Psittaciformes: Psittacidae & Unknown locality & Fain et al. (2000) \\
\hline $\begin{array}{l}\text { Syringophiloidus microcerculus Sikora et Skoracki, } \\
2012\end{array}$ & $\begin{array}{l}\text { Microcerculus marginatus } \\
\text { (Sclater) }\end{array}$ & $\begin{array}{l}\text { Passeriformes: } \\
\text { Troglodytidae }\end{array}$ & Pará & Sikora et al. (2012) \\
\hline Syringophiloidus stawarczyki Skoracki, 2004 & $\begin{array}{l}\text { Euphonia cyanocephala } \\
\text { (Vieillot) }\end{array}$ & Passeriformes: Fringillidae & Unknown locality & Skoracki (2004a) \\
\hline$"$ & Tachyphonus rufus (Boddaert) & Passeriformes: Thraupidae & Unknown locality & Skoracki (2004a) \\
\hline$"$ & Dacnis cayana (Linnaeus) & Passeriformes: Thraupidae & Minas Gerais & Present paper \\
\hline Syringophilopsis bonariensis sp. nov. & $\begin{array}{l}\text { Molothrus bonariensis } \\
\text { (Gmelin) }\end{array}$ & Passeriformes: Icteridae & Minas Gerais & Present paper \\
\hline Syringophiloidus parapresentalis Skoracki 2011 & Turdus rufiventris Vieillot & Passeriformes: Turdidae & Minas Gerais & Present paper \\
\hline Syringophilopsis tyranni Bochkov et Galloway, 2004 & Satrapa icterophrys (Vieillot) & Passeriformes: Tyrannidae & Minas Gerais & Present paper \\
\hline $\begin{array}{l}\text { Tinamiphilopsis ariconte Skoracki, Sikora et Ozminski, } \\
2012\end{array}$ & Nothura minor (Spix) & Tinamiformes: Tinamidae & Minas Gerais & Skoracki et al. (2012a) \\
\hline $\begin{array}{l}\text { Torotrogla synallaxis sp. nov. } \\
\text { Subfamily Picobiinae }\end{array}$ & Synallaxis spixi Sclater & Passeriformes: Funariidae & Minas Gerais & Present paper \\
\hline Neopicobia ea Skoracki et Unsoeld, 2014 & Celeus elegans (St. Müller) & Piciformes: Picidae & Bahia & Skoracki et al. (2014) \\
\hline Neopicobia ictericus (Skoracki et Glowska, 2010) & Cacicus chrysopterus (Vigors) & Passeriformes: Icteridae & Unknown locality & Skoracki et al. (2010) \\
\hline Picobia dryobatis (Fritsch, 1958) & Veniliornis maculifrons (Spix) & Piciformes: Picidae & Unknown locality & Skoracki et al. (2014) \\
\hline & $\begin{array}{l}\text { Veniliornis passerinus } \\
\quad \text { (Linnaeus) }\end{array}$ & Piciformes: Picidae & North Brazil & Skoracki et al. (2014) \\
\hline
\end{tabular}

50 (55), ve 75 (70), si 160 (170), se 155, c2 170 (170), d1 140 (160), d2 145 (140), e2 140 (150),f1 70 (55), f2 > 390, h1 125 (105), ps1 and ps2 25 (25), $g 1$ and $g 235$ (30-45), $3 b 55,3 c 75,4 b 50$ (50), 4c 85 (115), tc'III-IV and tc"III-IV 55 (60), I'RIII and I'RIV 40 (40-60).

Male. Unknown.

\section{Type material}

Female holotype and four female paratypes from Synallaxis spixi Sclater (Passeriformes: Funariidae), BRAZIL, Minas Gerais, Nova Lima, APP do Condomínio Miguelão, 2007'17.2" S 4358'03.1" W, 6 September 2010, coll. S.V. Mironov, F.A. Hernandes \& M.P. Valim (field no. SVM-10-0906-8/2).

\section{Types deposition}

Female holotype and two female paratypes are deposited in MZUSP, one female paratype in the AMU and one female paratype in the ZISP.

\section{Differential diagnosis}

Torotrogla synallaxis sp. nov. is morphologically similar to T. rubecul Skoracki, 2004 described from Erithacus rubecula (Linnaeus) (Muscicapidae) in Poland (Skoracki 2004b). In females of both species, the total body length is less than $1000 \mu \mathrm{m}$, the hypostomal protuberances are short and wide, setae $d 1$ are situated on the hysteronotal shields and setae I' of trochanters III do not extend beyond respective genua. The new species differs from $T$. rubeculi by the following features: in females of $T$. synallaxis, the hypostomal protuberances are blunt-ended; the propodonotal, hysteronotal and pygidial shields, as well as all coxal fields, are punctate; the length ratio of setae vi:ve:si is 1:1.5:3.2. In females of $T$. rubeculi, the hypostomal protuberances are sharp-ended; the propodonotal, hysteronotal and pygidial shields as well as all coxal fields are apunctate; the length ratio of setae vi:ve:si is 1:1:2.2-2.5.

\section{Etymology}

The specific epithet synallaxis is taken from the generic name of the type host

\section{Syringophilopsis bonariensis sp. nov.} (Figures $2(f-h)$ and $3(a, b))$.

\section{Description}

Female, holotype. Total body length 1135 (1100-1150 in 10 paratypes). Gnathosoma. Infracapitulum apunctate. Hypostomal apex with one pair of minute and sharp-ended protuberances. Each medial branch of peritremes with three chambers, each lateral branch with 14 chambers. Stylophore 260 (260-265) long, apunctate. Idiosoma. Propodonotal shield with deeply concave anterior margin, sculptured laterally and sparsely punctate at lateral margins, bearing bases of setae $v i$, ve, si and $c 1$, setae se on or near this shield. Length ratio of setae vi:ve:si 1:2-2.3:3.6-3.9. Setae se situated slightly anterior to level of setae $c 1$. Hysteronotal shield absent. Pygidial shield well sclerotized with rounded anterior margin, apunctate. Agenital setae ag1-3 about five times longer than genital setae g1-2. Coxal fields I-IV apunctate. Setae $3 c 1.4$ times longer than $3 b$. Legs. Fan-like setae $p^{\prime}$ and $p^{\prime \prime}$ of legs III and IV with 10-11 tines. Setae tc IIII-IV 1.4 times longer than tc'III-IV. Apodemes I fused with anterior part of apodemes II. Lengths of setae: $\mathrm{vi}$ 95 (90-110), ve 150 (190-215), si 340 (355), setae $c 1$, se, d1, d2, e2, f1, f2, $h 1, h 2$ longer than 300 , setae ag1, ag2, ag3 longer than $260, p s 1$ and ps2 30 (25-30), I'RI-III 20 (20), I'RIII-IV 35 (30-40), 91 (40-65), g2 (45-60), tc'III-IV (65-70), tc"III-IV 90 (100), 3690 (80-90), 4b 115 (95-115), 3c (130), 4c 150 (150-160). 


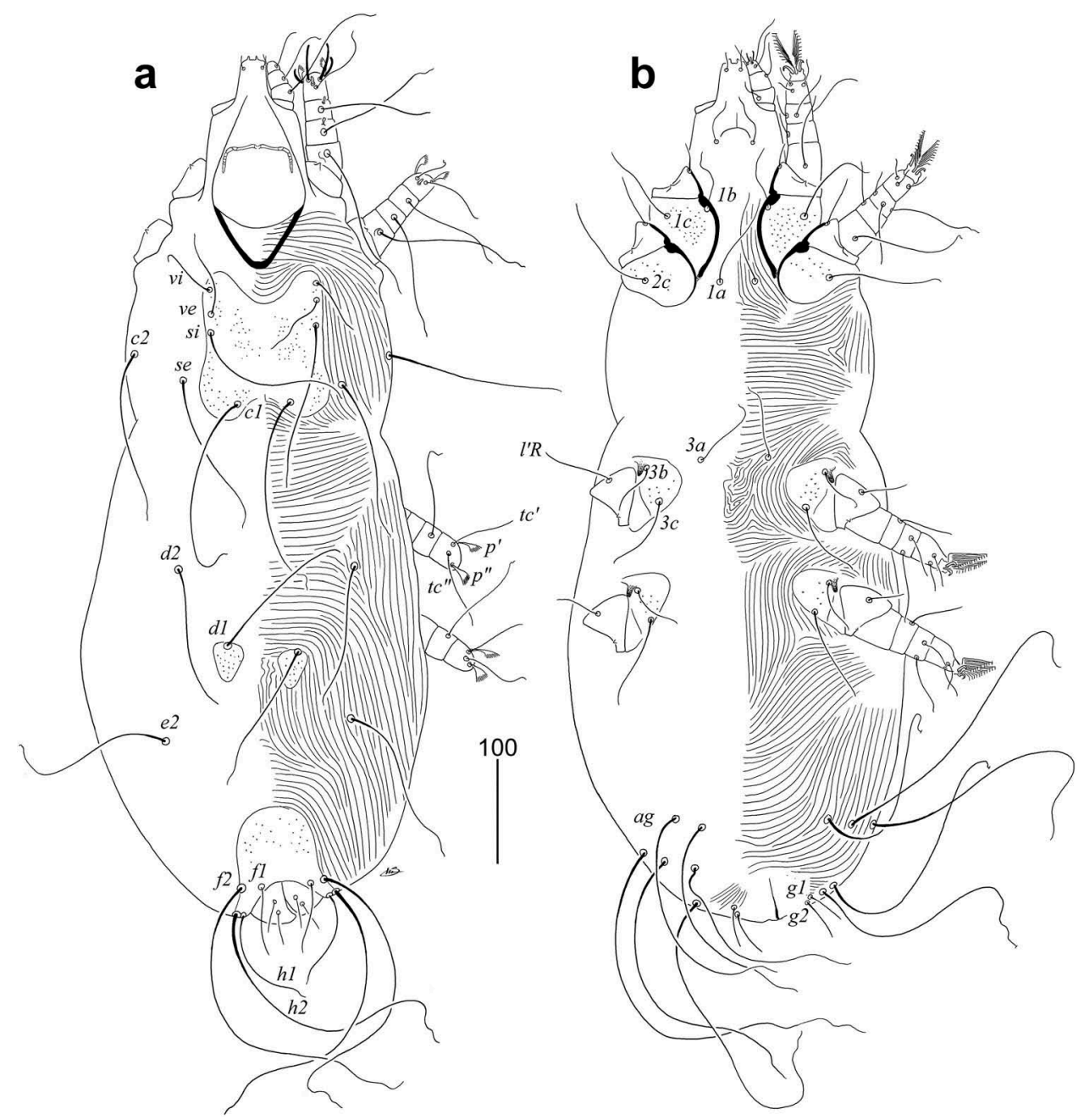

Figure 1. Torotrogla synallaxis sp. nov., female: (a) dorsal view; (b) ventral view.

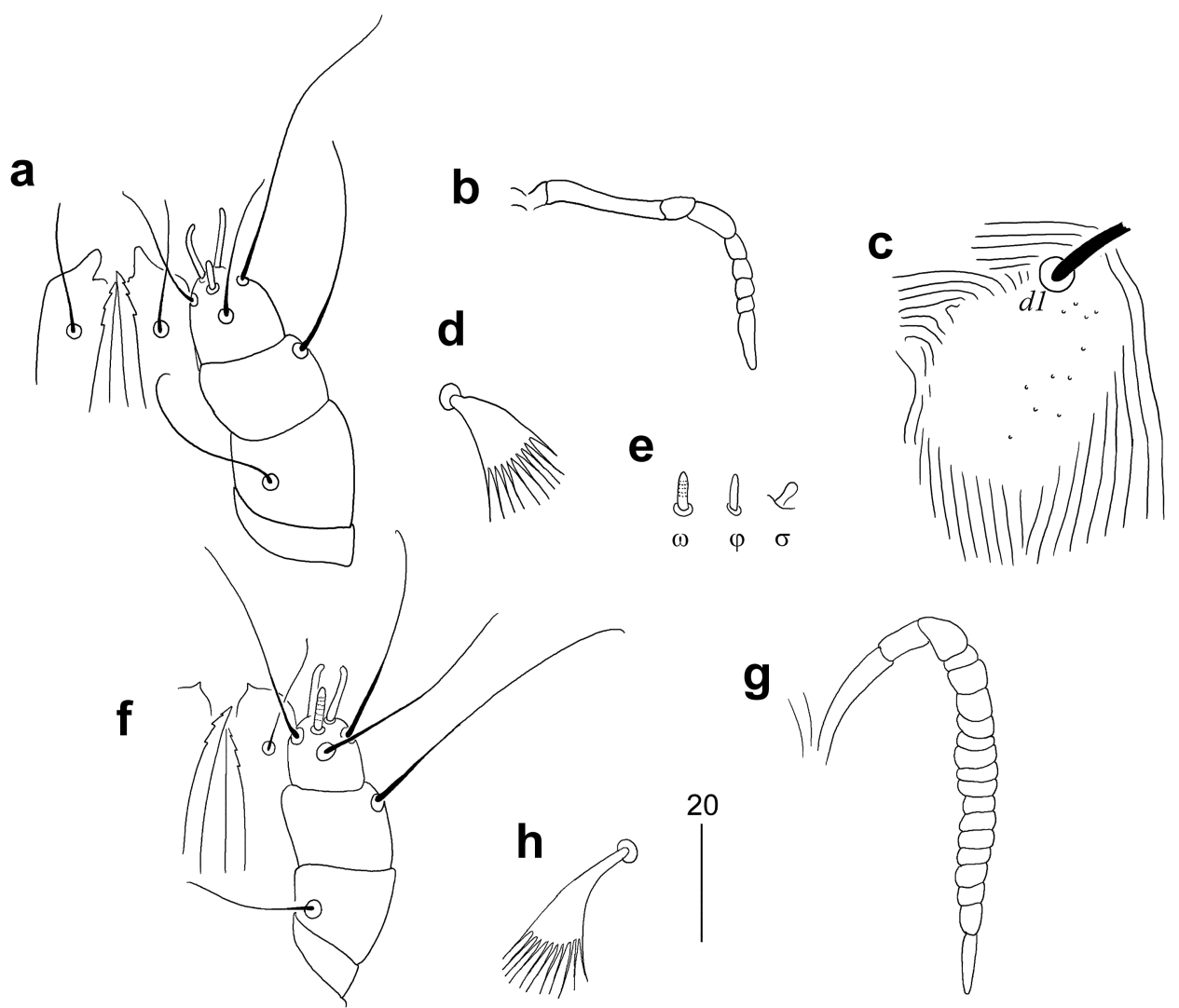

Figure 2. Torotrogla synallaxis sp. nov., female (a-e): (a) gnathosoma in ventral view; (b) peritreme; (c) hysteronotal shield; (d) fan-like seta $p^{\prime \prime l l l}$; (e) solenidia of leg I. Syringophilopsis bonariensis sp. nov., female (f-h): (f) gnathosoma in ventral view; (g) peritreme; (h) fan-like seta $p$ 'lll. 


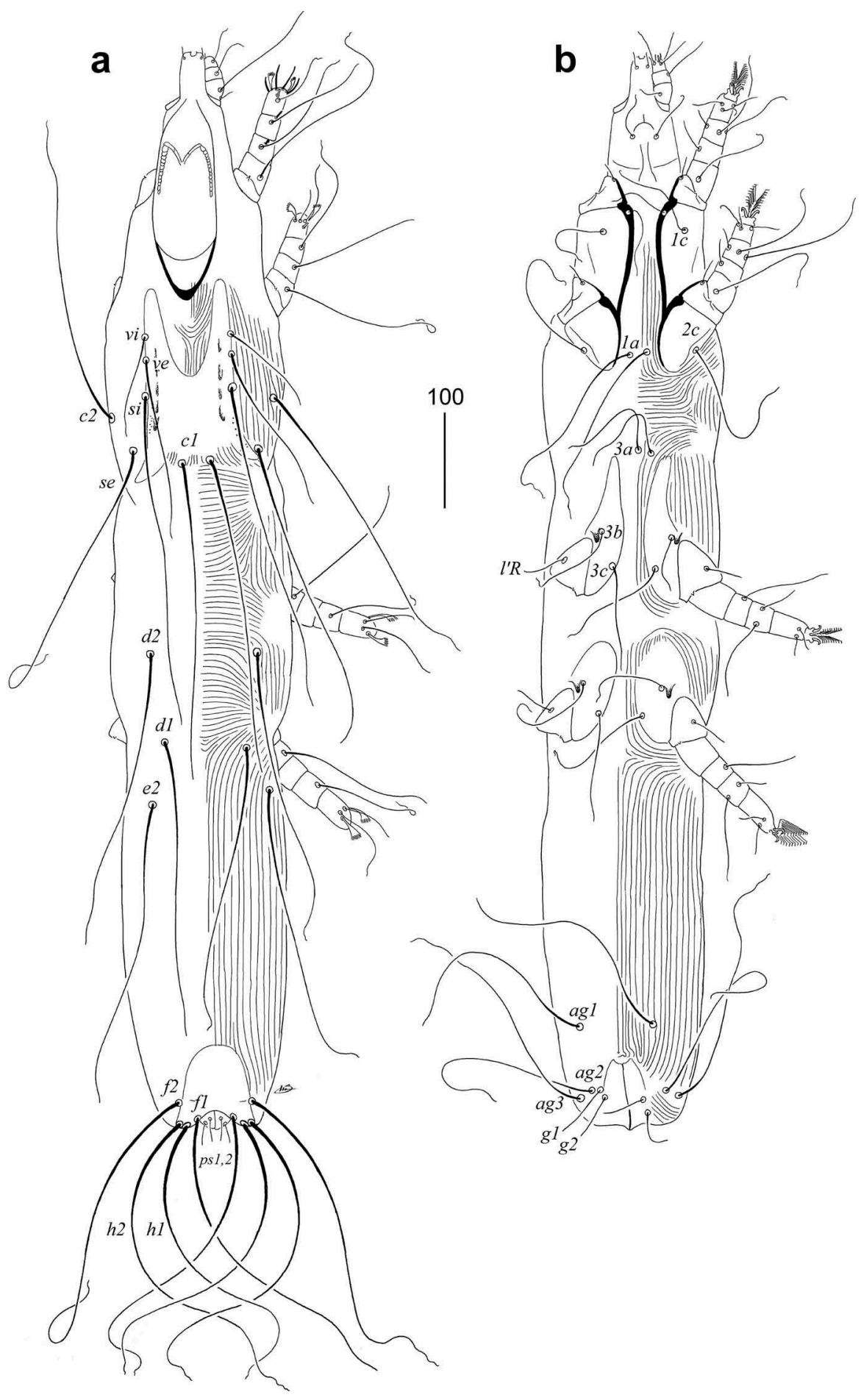

Figure 3. Syringophilopsis bonariensis sp. nov., female: (a) dorsal view; (b) ventral view.

Male. Unknown.

\section{Type material}

Female holotype and 18 female paratypes from Molothrus bonariensis (Gmelin) (Icteridae), BRAZIL, Minas Gerais, Nova

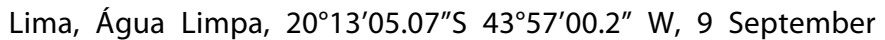
2010, coll. S.V. Mironov, F.A. Hernandes \& M.P. Valim (field no. SVM 10-0909-05).

\section{Types deposition}

Female holotype and 10 paratypes are deposited in MZUSP, 4 female paratypes in the AMU and 4 female paratypes in the ZISP.

\section{Differential diagnosis}

Syringophilopsis bonariensis sp. nov. belongs to the elongatus species group and is morphologically similar to S. tyranni Bochkov and Galloway, 2004 known from the tyrant flycatchers (Tyrannidae) in the Nearctic and Neotropical regions (see below). In females of both species, setae $v i$ are shorter than $160 \mu \mathrm{m}$, the hysteronotal shields are absent and genital setae are short (two to five times shorter than agenital setae ag2). The new species is distinguishable from $S$. tyranni by the following features: in females of $S$. bonariensis, setae se are situated slightly anterior to the level of setae $c 1$; the punctate area near bases of setae $d 1$ is absent; the pygidial shield is well sclerotized, with well-marked rounded anterior margin. In females of $S$. tyranni, setae se are 
situated distinctly anterior to the level of setae $c 1$; the punctate area near bases of setae $d 1$ is present; the pygidial shield is weakly sclerotized, with indistinct anterior margin.

\section{Etymology}

The name bonariensis is taken from the specific name of the type host.

\section{Syringophilopsis tyranni Bochkov et Galloway, 2004}

This species is associated with passerines of the family Tyrannidae and up to now it was recorded from Tyrannus tyrannus (Linnaeus) (type host) in Canada (Bochkov and Galloway 2004), T. dominicensis (Gmelin), T. forficatus (Gmelin), $T$. verticalis Say, Myiarchus crinitus (Linnaeus) and M. cinerascens (Lawrence), all hosts from the USA (Skoracki et al. 2008, 2016), and from Myiopagis subplacens (Sclater) in Peru (Glowska 2014). Below, we report a new host for this mite - Satrapa icterophrys (Vieillot); this is also the first record of this quill mite species in Brazil.

\section{Material examined}

Eight females and one male from Satrapa icterophrys (Vieillot) (Tyrannidae), BRAZIL, Minas Gerais, Nova Lima, Água Limpa, $20^{\circ}$ 13'05.07" S 4357'00.2"W, 31 August 2010, coll. S.V. Mironov, F.A. Hernandes \& M.P. Valim (field no. SVM 10-0831-7-2). Two females and one male are deposited in the AMU, three females in the ZISP and three females in the MZUSP.

\section{Syringophiloidus stawarczyki Skoracki, 2004}

Up to now, this species was recorded from the two avian hosts, Euphonia cyanocephala (Vieillot) (Fringillidae) (type host) and Tachyphonus rufus (Boddaert) (Thraupidae), both from Brazil (Skoracki 2004a). Below, we give a new host record for this quill mite species, Dacnis cayana (Linnaeus).

\section{Material examined}

Eleven females and two males from Dacnis cayana (Linnaeus) (Thraupidae), BRAZIL, Minas Gerais, Nova Lima, APP do

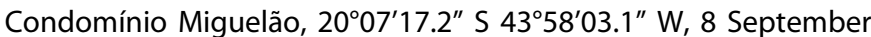
2010, coll. S.V. Mironov, F.A. Hernandes \& M.P. Valim (field no. SVM 10-0908-1-2). Three females and one male are deposited in the AMU, four females in the ZISP and four females and one male in the MZUSP.

\section{Syringophiloidus parapresentalis Skoracki, 2011}

This species is widely distributed on birds of the genus Turdus Linnaeus, and to this date it was recorded from Turdus atrogularis Jarocki (Turdidae) in Kazakhstan, T. iliacus Linnaeus in Russia, T. merula Linnaeus in Jordan, Kazakhstan and Poland, T. pilaris Linnaeus in Poland, Russia and Slovakia (Skoracki 2011) and T. migratorius Linnaeus in the USA (Skoracki et al. 2009, 2016). Below, we give a new host record - Turdus rufiventris Vieillot; it is also the first record of this species in the Neotropical region.

\section{Material examined}

Thirteen females and seven males from Turdus rufiventris (Turdidae), BRAZIL, Minas Gerais, Nova Lima, Água Limpa, $20^{\circ}$ 13'05.07" S 4357'00.2" W, 31 August 2010, coll. S.V. Mironov, F. A. Hernandes \& M.P. Valim (field no. SVM 10-0831-4-2). Five females and two males are deposited in the AMU, four females and two males in the ZISP and four females and three males in the MZUSP.

\section{Acknowledgements}

The authors thank the professors of Departamento de Parasitologia of Universidade Federal de Minas Gerais, Pedro M. Linardi for assistance in getting permission for "Expedição Científica" project (Expedição científica CNPq Proc. AEX n 591/ 2010-6, IBAMA license \#24789-1) and Alan L. Melo and Álvaro E. Eiras for help with field supplies and equipment used during collections. During the fieldwork, we had a support of the ornithologist Augusto Cezar Francisco Alves, for whom we are greatly thankful.

\section{Funding}

The study was supported for SVM by the General Biology Department of the Russian Academy of Science [theme no. 01201351187], for FAH by FAPESP - the São Paulo Research Foundation [grant 2011/50145-0], for MPV by FAPESP [grants 2011/11420-5; 2012/06951-4] and for MS by the German Academic Exchange Service - DAAD [grant A/12/05065].

\section{References}

Bochkov AV, Fain A. 2003. New and little known species of the family Syringophilidae (Acari: Cheyletoidea) from parrots (Aves: Psittaciformes). Acarina 11:37-44.

Bochkov AV, Fain A, Skoracki M. 2004. New quill mites of the family Syringophilidae (Acari: Cheyletoidea). Systematic Parasitology 57:135-150.

Bochkov AV, Galloway TD. 2004. New species and records of cheyletoid mites (Acari: Cheyletoidea) from birds in Canada. Journal of the Kansas Entomological Society 77:26-44.

Clements JF, Schulenberg TS, Iliff MJ, Roberson D, Fredericks TA, Sullivan BL, Wood CL. 2014. The eBird/Clements checklist of birds of the world: ver. 6.9 [Internet]. Ithaca (NY): The Cornell Lab Ornithology; [cited 2014 Aug 10]. Available from: http://www.birds.cornell.edu/clementschecklist/ download.

Fain A, Bochkov AV, Mironov SV. 2000. New genera and species of quill mites of the family Syringophilidae (Acari: Prostigmata). Bulletin de I'Institut Royal des Sciences Naturelles de Belgique 70:33-70.

Glowska E. 2014. New quill mites (Cheyletoidea: Syringophilidae) parasitizing tyrannid birds (Passeriformes: Tyrannidae) in Peru. Zootaxa 3814:139-145.

Glowska E, Chrzanowski M, Kaszewska K. 2015. Checklist of the Quill mites (Acariformes: Syringophilidae) of the World. Zootaxa 3968:1-81.

Grandjean F. 1939. Les segments postlarvaires de I'hysterosoma chez les oribates (Acariens). Bulletin de la Société Zoologique de France 64:273-284.

Grandjean F. 1944. Observations sur les Acariens de la famille des Stigmaeidae. Archives des Sciences Physiques et Naturelles 26:103-131.

Kethley JB. 1990. Acarina: prostigmata (Actinedida). In: Dindal DL, editor. Soil biology guide. New York (NY): Wiley and Sons; $p$. 667-754.

Piacentini VQ, Aleixo A, Agne CE, Maurício GN, Pacheco JF, Bravo GA, Brito GRR, Naka LN, Olmos F, Posso S, et al. 2015. Annotated checklist of the birds of Brazil by the Brazilian Ornithological Records Committee /Lista comentada das aves do Brasil pelo Comitê Brasileiro de Registros Ornitológicos. Revista Brasileira de Ornitologia 23:91-298.

Sikora B, Fajfer M, Kavetska K, Skoracki M. 2012. Three new species of quill mites (Acari: Syringophilidae) parasitizing the wrens (Aves: Troglodytidae). Zootaxa 3167:57-65.

Skoracki M. 2004a. A review of quill mites of the genus Syringophiloidus Kethley, 1970 (Acari: Prostigmata: 
Syringophilidae) parasitizing quills of passeriform birds, with descriptions of four new species. Genus 15:281-300.

Skoracki M. 2004b. New data on systematics of the quill mites of the genus Torotrogla Kethley, 1970 (Acari: Syringophilidae). Belgian Journal of Entomology 6:303-314.

Skoracki M. 2011. Quill mites (Acari: Syringophilidae) of the Palaearctic region. Zootaxa 2840:1-414.

Skoracki M, Flannery ME, Spicer GS. 2008. Quill mites of the genus Syringophilopsis Kethley, 1970 (Acari: Syringophilidae) from North American birds. Folia Parasitologica 55:291-300.

Skoracki M, Flannery ME, Spicer GS. 2009. New data on systematics of the quill mites of the genus Syringophiloidus Kethley, 1970 (Acari, Syringophilidae) from North American birds. Acta Parasitologica 54:64-72.

Skoracki M, Glowska E. 2008. Quill mites (Acari: Syringophilidae) associated with columbiform birds. Genus 19:151-160.
Skoracki M, Glowska E, Lontkowski J, Stawarczyk T. 2010. Picobia ictericus sp. n. (Acari: Prostigmata: Syringophilidae), an ectoparasite of two icterid bird species from Brazil. Genus 21:143-148.

Skoracki M, Sikora B, Ozminski M. 2012a. A new quill mite species (Acari: Syringophilidae) parasitising tinamous (Aves: Tinamiformes). Systematic Parasitology 81:109-113.

Skoracki M, Spicer GS, OConnor BM. 2016. A systematic review of the subfamily Syringophilinae (Acari: Syringophilidae) of the Nearctic region. Part 1: quill mites associated with passerines (Aves: Passeriformes). Zootaxa 4084:451-494.

Skoracki M, Unsoeld M, Kavetska K, Kaszewska K. 2014. Quill mites of the subfamily Picobiinae (Acari: Syringophilidae) associated with woodpeckers (Aves: Piciformes: Picidae). Acta Parasitologica 59:68-79.

Skoracki M, Zabludovskaya S, Bochkov AV. 2012b. A review of Prostigmata (Acariformes: Trombidiformes) permanently associated with birds. Acarina 20:67-107. 